\title{
The Implementation of Legal Certainty Principles in the Reporting Process of Debtor Bankruptcy Settlement by Curator to Supervisory Judge in Bankruptcy Practice*
}

\author{
Holyness N. Singadimedja ${ }^{* *}$, Rai Mantili***, Ema Rahmawati ${ }^{* * * *}$ \\ DOI: https://doi.org/10.22304/pjih.v5n3.a6
}

Submitted: November 13, 2018 | Accepted: December 28, 2018

\begin{abstract}
After a debtor is declared bankrupt by Commercial Court, the debtor loses the rights to control and to manage assets. Debtor's assets is under the management of curator, under surveillance of supervisory judge. Curator has important role in bankruptcy process since curator shall manage and maintain entire bankruptcy assets. Curator is expected to maximize value of bankruptcy assets to fulfill all debt obligations. Article 74 of the Law Number 37 of 2004 on Bankruptcy and Suspension of Payment, stipulates that curator must submit report to supervisory judge regarding the condition of bankruptcy assets and perform it quarterly. The report is disclosed to the public. The Article 74 is provision for supervisory judge to oversee curator's performance in debtor's bankruptcy settlement. Bankruptcy report from curator to supervisory judge in the Commercial Court can provide legal certainty for parties. In good faith, curator carries out duties and authorities to enforce the law on bankruptcy dispute resolution in Indonesia. The process of reporting debtors' bankruptcy assets, in practice, is not carried out properly since there are no specific standards regarding the report. Further, there are no sanctions for violating curator. Consequently, the regulation cannot perform legal certainty. It is necessary to standardize reports and sanctions for violations because the report an important aspects of bankruptcy process for parties. Furthermore, curator's responsibility to submit a report to supervisory judge is correlated to the principle of certainty in order to guarantee legal certainty as a principle of debt settlement. In Indonesia, the 1945 Constitution serves as a general ground; and the Law of Bankruptcy and Suspension of Payment functions as specific legal ground. If curator does not perform their duties properly, then they shall be responsible personally.
\end{abstract}

Keywords: bankruptcy assets, legal certainty, settlement report.

\section{Penerapan Prinsip Kepastian Hukum dalam Proses Laporan Pemberesan Harta Debitor Pailit oleh Kurator kepada Hakim Pengawas dalam Praktik Kepailitan}

\begin{abstract}
Abstrak
Setelah debitor dinyatakan pailit oleh Putusan Pengadilan Niaga, maka debitor kehilangan haknya untuk menguasai dan mengurus hartanya, sehingga segala pengurusan harta kekayaan debitor ada di bawah pengurusan kurator yang diawasi oleh Hakim Pengawas. Kurator memiliki
\end{abstract}

PADJADJARAN Journal of Law Volume 5 Number 3 Year 2018 [ISSN 2460-1543] [e-ISSN 2442-9325]

* This article is a part of the First Year Research of the Padjadjaran University's Internal Grant for Fundamental Research Scheme.

** Lecturer of the Faculty of Law, Padjadjaran University, Jl. Dipatiukur No. 35 Bandung, holyness@unpad.ac.id, S.H. (Universitas Mataram-NTB), M.H., Dr. (universitas Padjadjaran-Bandung).

*** Lecturer of the Faculty of Law, Padjadjaran University, Jl. Dipatiukur No. 35 Bandung, rai fdl@yahoo.com, S.H., M.H., (Universitas Padjadjaran), a Student of Doctoral Program of UGM Yogyakarta.

**** Lecturer of the Faculty of Law, Padjadjaran University, Jl. Dipatiukur No. 35 Bandung, ema.rahmawati@unpad.ac.id, S.H., M.H. (Universitas Padjadjaran), a Student of Doctoral Program of Universitas Padjadjaran Bandung. 
peranan yang sangat besar dan sangat penting dalam suatu proses kepailitan karena kurator harus mengelola dan mengurus seluruh harta pailit sehingga nilai harta pailit tersebut dapat dimaksimalkan untuk memenuhi seluruh kewajiban debitor pailit terhadap hak para kreditornya. Berdasarkan ketentuan Pasal 74 UUKPKPU, disebutkan bahwa kurator harus menyampaikan laporan kepada hakim pengawas mengenai keadaan harta pailit dan pelaksanaan tugasnya setiap 3 (tiga bulan). Tujuan Pasal 74 UUKPKPU adalah agar hakim pengawas dapat mengetahui sampai mana kinerja kurator dalam hal melakukan pemberesan harta pailit debitor. Adanya laporan pemberesan harta (boedel) pailit oleh kurator kepada hakim pengawas di Pengadilan Niaga dapat memberikan kepastian hukum bagi para pihak, dengan itikad baik kurator menjalankan tugas dan kewenangannya guna penegakan hukum penyelesaian sengketa kepailitan di Indonesia. Proses laporan pemberesan harta pailit debitor dalam praktiknya tidak dilaksanakan dengan baik mengingat tidak ada standar khusus mengenai laporan yang dimaksud dan tidak adanya sanksi bagi kurator yang melanggar, sehingga pengaturan mengenai kewajiban tersebut tidak dapat mewujudkan kepastian hukum dalam praktiknya. Oleh karena itu, perlu diatur secara tegas mengenai standar laporan dan sanksi bagi pelanggarannya, mengingat pelaporan atas pemberesan harta pailit ini merupakan salah satu aspek terpenting dalam proses kepailitan baik bagi debitor maupun bagi kreditor. Lebih lanjut lagi, tanggung jawab kurator mengenai laporan pemberesan harta pailit debitor kepada hakim pengawas dihubungkan dengan prinsip kepastian agar dapat menjamin kepastian hukum sebagai sarana penyelesaian utang piutang di Indonesia adalah UUD 1945 sebagai landasan umum dan UUKPKPU sebagai landasan khusus. Apabila Kurator yang tidak menjalankan tugasnya dengan baik atau lalai, maka dapat bertanggung jawab secara pribadi.

Kata kunci: asas kepastian hukum, harta pailit, laporan pemberesan.

\section{A. Introduction}

Creditor can do various ways to settle debts legally, including reconciliation both through the court and out of the court the court, civil lawsuits through the courts, alternative dispute resolution, requests for suspension of debt repayment obligation, or bankruptcy application through the Commercial Court. Bankruptcy has been known for a long time as one of the methods to settle debt, which aims to get payments or repayments on debtors' debts to creditor by repossession of debtor's assets. ${ }^{1}$

The bankruptcy decision rendered by the Commercial Court, as a judicial institution authorized in bankruptcy, has brought new legal consequences. It may cause a new effect. Because of the new law, debtor who was originally authorized to manage and control property became no longer authorized to take care and control assets. ${ }^{2}$ After a debtor is declared bankrupt by the decision of the Commercial Court, the debtor loses rights to control and to manage property. A curator, who is assigned by the Commercial Court, is responsible to manage all debtor's assets. In performing the duties, the curator is supervised by a Supervisory Judge.

1 Ema Rahmawati, "Putusan Pailit Sekutu Pengurus Persekutuan Komanditer (CV) Atas Utang Perusahaan Dalam Kajian Hukum Kepailitan dan Kitab Undang-Undang Hukum Dagang", Postgraduate Thesis, the Faculty of Law, Padjadjaran University, 2009, p. 8.

2 Man S Sastrawidjaja, Hukum Kepailitan dan Penundaan Kewajiban Pembayaran Utang, Bandung: PT Alumni, 2006, p. 101. 
Curator has a major and important role in a bankruptcy process since a curator shall manage and maintain all bankruptcy assets. A curator is expected to maximize value of bankruptcy assets to fulfill all obligations of bankrupt debtor to creditor. In carrying out the duties, curator must act independently as stated in Article 15 (3), of the Law Number 37 of 2004 on Bankruptcy and Suspension of Payment (Bankruptcy and Suspension of Payment Law), including from the parties who proposes the curator.

Since the date of bankruptcy decision is stated, debtor is no longer permitted to manage assets that have been declared bankrupt (bankruptcy assets). Furthermore, management of bankruptcy estate is handed over to a curator appointed by the court, which is supervised by the appointed supervisory judge. The appointment shall be determined in the bankruptcy statement. The curator's management of bankruptcy estate is instantaneous and is valid from the date of the decision, even though the decision is then appealed (kasasi) or reviewed. ${ }^{3}$ If the bankruptcy decision is canceled by an appeal (kasasi) or judicial review decision, all actions that have been carried out by the curator before, or on the date the curator receives notification of the cancellation decision, are still valid and binding to the bankrupt debtor. ${ }^{4}$

Article 74 (1) and (2), of the Bankruptcy and Suspension of Payment Law states the following.

(1) Kurator harus menyampaikan laporan kepada Hakim Pengawas mengenai keadaan harta pailit dan pelaksanaan tugasnya setiap 3 (tiga) bulan.

[(1) The curator must submit a report to the Supervisory Judge regarding the condition of the bankruptcy assets and and shall be performed every 3 (three) months.]

(2) Laporan sebagaimana dimaksud pada ayat (1) bersifat terbuka untuk umum dan dapat dilihat oleh setiap orang dengan cuma-cuma.

[(2) Reports as referred to in paragraph (1) are open to the public and can be seen by everyone for free".]

Based on the Article 74, curator shall submit report to the supervisory judge regarding condition of bankruptcy assets and perform such duties in every three months. The report is open to the public and can be seen free of charge. According to the Indonesian Dictionary (KBBI), the word harus (literally: must/shall) has an appropriate and obligatory meaning; or should be done. This means that the Article 74 requires curator to submit a bankruptcy management report to supervisory judge.

The Article 74 is also an instrument for the supervisory judge to know the performance of curator in the settlement of debtor's bankruptcy. The purpose of such settlement is a situation where curator conduct payment to creditor from the proceeds of the sale of bankruptcy assets. Article 16 (1) of the Bankruptcy and Suspension of Payment Law explains that settlement is the liquidation of assets in order to pay or settle the debt. A settlement can only be conducted after debtor is in insolvency phase, which such insolvency can occur under the following situations. ${ }^{5}$

Poppy Indaryati, “Diskriminasi Kurator di dalam Kepailitan”, Postgraduate Thesis, Universitas Dipenogoro, p. 38.

Achmad Yani dan Gunawan Widjaja, Seri Hukum Bisnis Kepailitan, Jakarta: PT RajaGrafindo Persada, 2002, p. 62.

Article 178 (1) of the Law Number 37 of 2004 on Bankruptcy and Suspension of Payments. 
1. There is no accord plan being proposed in the debt verification meeting.

2. There is an accord plan being proposed, whether by the debtor or creditor, but such accord plan is not approved by the creditor it in the debt verification meeting.

3. There is accord plan and approved by creditor in debt verification meeting but it does not obtain homologation (certification) from the bankrupt rendering judge.

Curator's duties and authorities to manage and to settle bankruptcy assets need further guidance in the Law of Bankruptcy and Suspension of Payment. The obligation of curator to report bankruptcy assets settlement to the supervisory judge as required in Article 74 (1), in practice, is often ignored since there are no specific guidelines regarding the reporting. There is even no sanction for curator who does not perform such duties. This might cause disadvantage for the bankrupt debtor, creditor, and curator him/herself because the disclosure principle as stipulated in such Article 74 paragraph (2) is not fulfilled. The current fact is, many debtors and creditors are reporting their curators to the police.

As one of the options for debt payment methods, the Law of Bankruptcy and Suspension of Payment is aimed to protect creditors by providing a clear and definite way to settle outstanding debts. General explanation of the Law of Bankruptcy and Suspension of Payment (which replaces the Law Number 4 of 1998) firmly adheres to the principles of balance, business continuity, justice, and integration. An equal protection of interests is in line with the states ground of the Republic of Indonesia, namely Pancasila. Pancasila recognize either individual or communal interests.

According to Kusumaatmadja, the role of law in national development is to ensure that every change occurs in an orderly manner. Regularity and orderliness in development or reform are absolutely needed. Kusumaatamadja also states that in addition to establish an orderly environment, another goal of law is to achieve justice, which has various content and size according to society and its time. To create an orderly environment, legal certainty is needed. ${ }^{6}$ In this regard, the point a of consideration of the Law of Bankruptcy and Suspension of Payment states that the development of national law in the context of creating a just and prosperous society that is based on Pancasila and the 1945 Constitution must guarantee legal certainty.

Based on the description above, this study analyzed in this article is regarding the reporting process of debtor's bankruptcy assets settlement in the Law of Bankruptcy and Suspension of Payment in its relevance to legal certainty; and the obligation of curator in respect of report of debtor's bankruptcy assets settlement to the supervisory judge in its relevance to the principle of legal certainty.

To the best of our knowledges, no one has ever discussed curator's report of bankruptcy assets to supervisory judge, both in journals and in other scientific works. Some works that have already discussed bankruptcy and curators in the last three years includes Mufti's Tanggung Jawab Kurator Dalam Penjualan Harta Pailit Di Bawah Harga Pasar [Curator's responsibility in the sale of bankruptcy estate under market prices] in the journal Lex Renaisance No. 1 Vol. 1, dated January 1, 2016; Martina's Peranan Kurator Dalam Kepaiitan Terhadap Masalah Bank [The Role of Curator in the

6 Mochtar Kusumaatmadja, Hukum, Masyarakat dan Pembinaan Hukum Nasional, Bandung: Bina Cipta, 1976, p. 3. 
Issue of Bank] in the journal Kerta Wicaksana Vol. 21 No. 1, dated January 2017; and Arkisman's Pelaksanaan Tugas Kurator Dalam Mengurus Harta Pailit Berdasarkan Pasal 72 Undang-Undang No. 37 Tahun 2004 Tentang Kepailitan Dan Penundaaan Kewajiban Pembayaran Utang [The Implementation of Curatorial Tasks in Managing Bankruptcy estate under Article 72 of the Bankruptcy and Suspension of Payment Laws] in the Pro Legal Journal Vol. IV No. 1, dated June 1, 2015.

The specific purpose of this study is to obtain a juridical basis on the provisions of the debtor's bankruptcy report in the Law of Bankruptcy and Suspension of Payment to guarantee legal certainty and to obtain legal provisions on the responsibility of curator to report bankrupt-debtor's assets to resolve bankruptcy processes in Indonesia. This study is expected to contribute ideas and to extend law understanding of the development of corporate and bankruptcy laws within academic communities. In addition, the study is expected to contribute to the development of legal science, which can lead to the contributions of the legal ideas in general and the development of corporate and bankruptcy laws.

This article is based on a research using normative judicial research method. The research specification is analytical description in order to obtain description of facts and data analysis. The data obtained in this research is secondary data and primary data of several problems in relation to the performance of debt settlement and debtor's asset settlement by curator, and relevant prevail regulation in relation with the legal theory and principle. The data collection method is library research of relevant national regulation. In addition to the library data, empirical data is also used as primary data to complete library research. Empirical data required to obtain description of report of debtor's asset settlement by curator in practice. The collection of such primary data is conducted through interview with, i.e., Advisory Board and Counsellor of Indonesian Care Taker and Curator Association (AKPI), judges of Commercial Court at the several Indonesia Commercial Court. The data is analyzed using the qualitative method and described descriptively.

\section{B. The Process of Reporting Debtor-Bankruptcy Assets in the Law Of Bankruptcy And Suspension of Payment in Its Relevance to Legal Certainty}

The emergence basis of bankruptcy is debt issue. Debt, in broad term, according to Article 1 (6) of the Law of Bankruptcy and Suspension of Payment is as follows.

"kewajiban yang dinyatakan atau dapat dinyatakan dalam jumlah uang baik dalam mata uang Indonesia maupun mata uang asing, baik secara langsung maupun yang akan timbul di kemudian hari atau kontijen, yang timbul karena perjanjian atau undang-undang dan wajib dipenuhi oleh debitor dan bila tidak dipenuhi memberi hak kreditor untuk mendapat pemenuhannya dari harta kekayaan debitor".

[Obligation that is stated or can be stated in the amount of money, both in Indonesian and foreign currencies, directly or contingent, which arises due to agreements or laws and must be fulfilled by debtor; and if it is not fulfilled, it gives creditor the right to get fulfillment from debtor's assets.] 
In the legal dictionary, bankruptcy is the condition when a debtor has stopped paying debt. After such party, at the request of creditor or debtor to the court, is declared bankrupt, the party's assets are controlled privately by the inheritance center (BHP) as the curator to be used for the interest of all creditors. The inability of a debtor to pay debt must be accompanied by a concrete action to submit assets, either it is done voluntarily by the debtor himself or at the request of a third party (creditor) to the court.

In the Black's Law Dictionary, bankruptcy or bankrupt is "the state or condition of a person (individual, partnership, corporation, municipality) who is unable to pay its debt as they are, or became due". The term includes a person against whom an involuntary petition has been filled who has filed a voluntary petition, or who has been adjudged a bankrupt. Thus, it can be seen that the notion of bankruptcy is related to the "inability to pay" from a person (debtor) for the debt that are due. Such incompetence must be accompanied by a concrete action to submit assets, either it is done voluntarily by the debtor himself or at the request of a third party (creditor) to the court. The purpose of submitting the application is to fulfill the principle of "publicity" of a debtor's condition of being unable to pay.

The formulation of Article 2 (1), of the Law of Bankruptcy and Suspension of Payment defines bankruptcy or bankrupt as a condition where a debtor is unable to repay debt on due date. A bankruptcy statement may not be declared of one's own free will. It must be preceded by a bankruptcy statement by the court either on debtor's own voluntary application or at the request of one or more third parties (creditors). The definition of 'debtor', according to the Article 1 (3) of the Bankruptcy and Suspension of Payment Law, is a person who has a debt due to an agreement or law that the repayment can be billed in the court session. Article 2 (1), of the Bankruptcy and Suspension of Payment Law states that a debtor who has two or more creditors and does not pay in full at least one debt that has matured and can be billed, is declared bankrupt with a court decision, either by own request and on request made by one or more creditors. As long as the debtor has not been declared bankrupt by the court, during that time the person concerned is still considered capable of paying debts that are due. This bankruptcy statement is intended to avoid the confiscation and execution of individuals on the assets of debtor who are no longer able to pay debts.

The General Explanation of the Bankruptcy and Suspension of Payment Law mentions several regulatory factors regarding bankruptcy and suspension of payment, including

(1) to avoid the dispute for debtor's assets if at the same time there are several creditors who collect the accounts from the debtor;

(2) to avoid the existence of creditors holding material security rights that demand their rights by selling debtor property without regard to the interests of the debtor or other creditors; and

(3) to avoid cheating by one of the creditors or the debtor.

Based on the explanation of the Bankruptcy and Suspension of Payment Law, it can be said that the law has a good function for the benefit of both creditors and debtors. 
Creditor can do various ways to settle debt legally, including amicable efforts both inside and outside the court, civil lawsuits through the court, using alternative dispute resolution, requesting for debt repayment obligation, or bankruptcy request through the Commercial Court. Bankruptcy has been known for a long time as one of the ways to settle debt, which aims to get payments or repayments of debtors' debt to creditors by way of public confiscation of the debtor's wealth.

The Commercial Court, as a judicial institution authorized in bankruptcy declaration, decide bankruptcy. It may cause a new effect. Because of the new law, debtor who was originally authorized to manage and control property became no longer authorized to take care and control assets.

After a debtor is declared bankrupt by the decision of the Commercial Court, the debtor loses rights to control and to manage assets, accordingly, a curator who is assigned by the Commercial Court, is responsible to manage all debtor's assets. In performing the duties, the curator is overseen by a Supervisory Judge. Curator has major and important role in a bankruptcy process because a curator must manage and maintain all bankruptcy estate. A curator is expected to maximize value of bankruptcy estate to fulfill all obligations of bankrupt debtor to creditor. In carrying out the duties, curator must act independently as stated in Article 15 (3), of the Bankruptcy and Suspension of Payment Law, including from the parties who proposes the curator.

Since the date of bankruptcy decision, debtor is no longer permitted to manage assets that have been declared bankrupt (bankruptcy estate). Furthermore, management of bankruptcy estate is handed over to a curator appointed by the court, which is overseen by the appointed supervisory judge. The appointment must be determined in the bankruptcy statement. The curator's management of bankruptcy estate is instantaneous and is valid from the date of the decision, even though the decision is then appealed or reviewed. If the bankruptcy decision is canceled by a cassation or review decision, all actions that have been carried out by the curator before, or on the date the curator receives notification of the cancellation decision, are still valid and bind on the bankrupt debtor.

Based on the Article 74, curator must submit report to supervisory judge regarding condition of bankruptcy estate and execution of their duties in every three months. The report is open to the public and can be seen free of charge. According to the Big Indonesian Dictionary (KBBI), the word harus (literally: must) has an appropriate and obligatory meaning; or should be done. This means that the Article 74 requires curator to submit a bankruptcy management report to supervisory judge.

The Article 74 is also a guidance for supervising judge to know the performance of curator in the settlement of debtor's bankruptcy. The purpose of the settlement here is a situation where curator makes payment to creditor from the proceeds of the sale of bankruptcy estate. Article 16 (1), of the Bankruptcy and Suspension of Payment Law explains that settlement is the transfer of assets to pay or repay debt. A settlement can be made after debtor is in a state of insolvency, which can occur under the following three situations.

1. There is no accord plan being proposed in the debt verification meeting. 
2. There is an accord plan being proposed, whether by the debtor or creditor, but such accord plan is not approved by the creditor it in the debt verification meeting.

3. There is accord plan and approved by creditor in debt verification meeting but it does not obtain homologation (certification) from the bankrupt rendering judge.

The duty of curator, in general, is to manage and maintain all bankruptcy assets. Therefore, a curator must act for the best interests of creditor and pay attention to the interests of bankrupt debtors. These interests must not be ignored at all. ${ }^{7}$ The important thing that must be considered by a curator in carrying out the duties is that not all authorities can be carried out freely. In fact, it is strongly recommended that all curator's activities must be consulted with or even approved by the supervisory judge, including in matters that are not regulated by the law to request consultation and approval from the supervisory judge. ${ }^{8}$

The most basic duty of the curator is to carry out management and settlement of bankruptcy. In carrying out this task, the curator has the main vision to make the best decision to maximize the value of bankruptcy estate. ${ }^{9}$ Assets are the most important factor in debt settlement through bankruptcy.

Curator, in carrying out the duties, is independent from both debtor and creditor. Every decision that they make are not required to obtain approval from, or submit prior notice to, debtor or creditor. ${ }^{10}$ The tasks of the curator in detail include the following. $^{11}$

1. Announcing the decision of bankruptcy statement, place and time of the first creditors' meeting in the State Gazette of the Republic of Indonesia and two daily newspapers determined by the Supervisory Judge, within a maximum period of five days from the decision of the bankruptcy statement (Article 15 paragraph [4] of the Bankruptcy and Suspension of Payment Law).

2. Seeking bankruptcy estate security by storing all letters, documents, money, jewelries, obligations, and other securities by providing receipts (Article 98 of the Bankruptcy and Suspension of Payment Law);

3. Making a registration of bankruptcy estate no later than two days after receiving the letter of decision of the appointment as curator (Article 100 of the Bankruptcy and Suspension of Payment Law) and subsequently making a list of the nature and number of receivables along with their respective creditors (Article 102 UUK). The recording of bankruptcy estate as referred to in Article 100 and the list as referred to in Article 102 must be placed in the Registrar's Office to be seen by anyone for free (Article 103 of the Bankruptcy and Suspension of Payment Law).

4. Announcing, in two daily newspapers, the deadline for filing creditors' bills, the day, the date, the time, and the place of meeting the accounts receivable

Imran Nating, Peranan dan Tanggung Jawab Kurator dalam Pengurusan dan Pemberesan Harta Pailit, Jakarta: PT Raja Grafindo Persada, 2004, p. 70.

8 Munir Fuady, Hukum Pailit dalam Teori dan Praktek, Bandung: PT Citra Aditya Bakti, 2014, p. 50.

9 Dewi Tuti Maryati (et.al), "Pengaturan Tanggung Jawab Kurator Terhadap Pengurusan dan Pemberesan Harta Pailit dalam Kaitannya dengan Hak Kreditor Separatis", Jurnal Dinamika Sosial Budaya, Vol. 19, No. 1, Juni 2017, p. 15.

10 Achmad Yani dan Gunawan Widjaja, Op.cit., p. 63.

11 Gunawan Widjaja, Risiko hukum \& Bisnis Perusahaan Pailit, Jakarta: Forum Sahabat, 2009, p. 109. 
matching, which are determined by the Supervisory Judge (Article 114 of the Bankruptcy and Suspension of Payment Law).

5. Matching the incoming bills (Article 116 of the Bankruptcy and Suspension of Payment Law).

6. Making a list of receivables that are temporarily recognized and disputed (Article 117 of the Bankruptcy and Suspension of Payment Law).

7. Providing a copy of the list of receivables, which are temporarily recognized; and which are temporarily denied in the Registrar's Office (Article 119 of the Bankruptcy and Suspension of Payment Law).

8. Notifying the list of receivables which are temporarily recognized and disputed to all creditors of, and calling for the meeting of accounts receivable matching (Article 120 of the Bankruptcy and Suspension of Payment Law).

9. Providing a report on the condition of bankruptcy estate, after the meeting of accounts receivable matching (Article 143 [1], of the Bankruptcy and Suspension of Payment Law).

10. Providing written opinions on the amicable plan (Article 146 of the Bankruptcy and Suspension of Payment Law).

11. Making/compiling a distribution list and requesting approval from the Supervisory Judge (Article 189 [1], of the Bankruptcy and Suspension of Payment Law) and placing a list of shares that have been approved by the Supervisory Judge in the Registrar's Office to be seen by creditors during the time period stipulated by the Supervisory Judge (Article 192 of the Bankruptcy and Suspension of Payment Law).

12. Executing the stipulated distribution (Article 201 of the Bankruptcy and Suspension of Payment Law).

13. Announcing an overview of bankruptcy expiration in a newspaper appointed by the Supervisory Judge and in the State Gazette (Article 202 [2], of the Bankruptcy and Suspension of Payment Law).

14. Providing accountability regarding the task of management and the settlement to the Supervisory Judge (Article 202 [3], of the Bankruptcy and Suspension of Payment Law).

The process of reporting a bankruptcy estate by the curator to the supervisory judge must always be made in every three months as stipulated in Article 74 of the Bankruptcy and Suspension of Payment Law. Matters reported are the performance of the curator in the debtor's bankruptcy settlement, including the distribution of bankruptcy estate as follows. ${ }^{12}$

1. Assets that are not bankruptcy assets must be excluded first.

2. All debts of bankruptcy assets must be discharged from the debtor's bankruptcy assets.

3. Secured creditors can execute their debt guarantees respectively.

4. Secured creditors is in the highest order, unless otherwise specified.

5. Bankruptcy costs must take precedence after secured creditors.

12 Cholidah Utama, "Tanggung Jawab Hakim Pengawas dalam Pengurusan Harta Debitor Pasca Pailit", Jurnal Muamalah, Vol. 3, No. 1, 2017, p. 47. 
6. The privilege receivables on certain goods must take precedence over receivables in general.

7. Receivables are sorted according to the rules of the Civil Law.

8. Concurrent creditors' receivables are divided based on Pro Rata.

9. If there are excess assets, the receivables are returned to the bankrupt debtor.

Based on the study, there is no specific format of the curator's report of the debtor's bankruptcy estate. Curator only uses conventional format based on jurisprudence. ${ }^{13}$ Despite the fact that Article 74 of the Bankruptcy and Suspension of Payment Law require every curator to submit a report to the supervisory judge regarding the condition of bankruptcy estate and the execution of their duties in every three months, there is no sanction for curator who does not fulfill the obligation. Therefore, the Supreme Court issued the Circular of the Supreme Court Number 2 of 2016 (the Circular of Bankruptcy Case Efficiency), which gives the authority to Supervisory Judge to summon and to request a curator's explanation, to give a warning to curator, and to propose replacement of curator to the panel of commercial judges. Some curators criticize the circular because according to Article 74 (1), of the Bankruptcy and Suspension of Payment Law, curator must submit a report to Supervisory Judge in every three months. It means that the time for reporting has been determined by the Law. Consequently, there is no need for supervisory judge to call and to ask curator to provide an explanation. Simanjuntak criticizes the Circular because the substance is allegedly in contradiction with the Bankruptcy and Suspension of Payment Law. Since there is clear order of laws and regulations, the Circular must not conflict the Law. ${ }^{14}$ Based on Article 74 of the Bankruptcy and Suspension of Payment Law, curator tasks only cover compliance and disclosure of information by report in every three months and providing ease of access for debtors and creditors to the development of management and settlement process.

As previously explained, the obligation to submit a report on the debtor's bankruptcy repayment to supervisory judge is intended to, among other things, provide legal certainty for various parties in a bankruptcy process. Legal certainty is one of the principles or the norms that inspire regulatory norms in bankruptcy.

Legal certainty can be meant that someone will be able to get something expected in certain circumstances. Certainty is defined as norm clarity so that it can be used as a guideline for the people who are subject to regulation. Certainty can be defined as clarity and firmness towards the enactment of law among people. This is not to cause a lot of misinterpretation. Legal certainty is the existence of clarity on general behavior scenarios that binds all citizens, including the legal consequences. Legal certainty can also mean things that can be determined by law in concrete matters. ${ }^{15}$ Legal certainty is a guarantee that the law is implemented, which those who are entitled according to

13 A result of the Interview with James Purba, Chairperson of the Indonesian Curator Association on August 21, 2018.

14 Hukum Online, "Kurator Tanggapi Sema Efisiensi Perkara Kepailitan", https://www.hukumonline.com/berita/baca/It57d22b7635191/kurator-tanggapi-sema-efisiensi-perkara-kepailitan, accessed on October 2018.

15 Van Apeldoorn in Tata Wijayanta, "Asas Kepastian Hukum, Keadilan dan Kemanfaatan dalam Kaitannya dengan Putusan Kepailitan Pengadilan Niaga", Jurnal Dinamika Hukum, Vol. 14, No. 2, 2014, p. 219. 
law, can obtain their rights; and that the verdict can be implemented. Legal certainty is a justified protection against arbitrary actions. It means that someone will be able to get something expected in certain circumstances. Law is in charge of creating legal certainty because it aims to create order in society. Legal certainty is a characteristic that cannot be separated from the law, especially for written law. Law without the value of legal certainty will lose its meaning because it can no longer be used as a guideline for everyone. ${ }^{16}$

In principle, the Bankruptcy and Suspension of Payment Law provides the concept of legal certainty, benefits, and justice through several principles in resolving bankruptcy cases. The principle of legal certainty is summed up in the principle of solving cases quickly and the principle of simple proving. ${ }^{17}$ Legal certainty in the settlement is also related to the procedure for proceedings in bankruptcy, including in the context of the depositing of bankrupt debtor assets that are very important for the repayment of bankrupt debtors' debt.

As previously explained, there is no specific format of the curator's report of the debtor's bankruptcy assets. Curator only uses conventional format based on jurisprudence, or custom practice among members of the same association. In addition, the obligation to submit reports regularly in every three months does not include sanctions against violators. This shows that the current arrangement cannot provide legal certainty in curator's reporting process to supervisory judge. The uncertainty covers the material and the format submitted to supervisory judge, as well as legal consequences or sanctions for curator who does not fulfill this obligation. That is what makes this important matter in practice often overlooked. Thus, in the end, it creates legal uncertainty. Given that legal certainty is to create order and harmony, legal uncertainty will result in irregularities and lack of orderly procedures of reporting bankruptcy assets.

\section{Curator's Obligation to Report Debtor's Bankruptcy Settlement to Supervisory Judge in the Context of Legal Certainty Principle}

Article 1 (3), of the 1945 Constitution states that Indonesia is a legal state. Paragraph 4 of the Preamble explains that the state aims to protect the whole people of Indonesia and the entire homeland of Indonesia, and in order to advance general prosperity, to develop the nation's intellectual life, and to contribute to the implementation of a world order based on freedom, lasting peace and social justice, Indonesia's National Independence shall be laid down in a Constitution of the State of Indonesia, which is to be established as the State of the Republic of Indonesia with sovereignty of the people and based on the belief in the One and Only God, on just and civilized humanity, on the unity of Indonesia and on democratic rule that is guided by the strength of wisdom resulting from deliberation / representation, so as to realize social justice for all the people of Indonesia.

16 Fence M. Wantu in Tata Wijayanta, ibid., pp. 219-220.

17 Syafrudin Makmur, "Kepastian Hukum Kepailitan Bagi Kreditur dan Debitur Pada Pengadilan Niaga Indonesia", Mizan Jurnal Ilmu Syariah, Vol. 4, No. 2, 2016, p. 364. 
As a legal state, Indonesia's development in the field of law is a part of national development because law, as a means of renewing society, cannot be left behind from the processes of development. Likewise, there is a correlation between development in the field of economy and in the field of law. One of the developments in the field of economics is the rapid dynamics of the business world, which have quite fundamental implications for legal institutions and organizations.

Implications for legal institutions are caused by inadequate sets of norms to support rapid economic and business activities. This condition is attempted to be overcome by carrying out legal reform in the field of economics. Various efforts have been made through the renewal of the substance of legal products that have been left behind as well as by making new laws and regulations on fields that support economic and business activities. To anticipate the development of trade and business, in addition to the accommodation of laws and regulations, instruments and law enforcement that do not impede trade and business also support it. Furthermore, the efforts are expected to be able to resolve disputes among parties who feel harmed by other parties. In this case, the law will play a role to protect the interests of parties, so that no one is harmed by the other party's benefits.

Curator is appointed after debtor is declared bankrupt. Because of bankruptcy, debtor loses the right to manage assets and, therefore, the authority to manage bankruptcy estate falls to curator. Of the various types of tasks for the Curator in carrying out the management and settlement, it can be concluded that curator has several main tasks as follows.

1. Administrative Duties. In its administrative capacity, curator administers processes that occur in bankruptcy settlement. It includes, among others, making announcements (Article 13 (4) of the Bankruptcy and Suspension of Payment Law); inviting creditor meetings; securing the assets of the bankrupt debtor; conducting an inventory of bankruptcy estate (Article 91 of the Bankruptcy and Suspension of Payment Law); and reporting progress to supervisory judge (Article 70B [1], of the Bankruptcy and Suspension of Payment Law). In carrying out its administrative capacity, curator has authorities, among others, to (1) make coercive acts, such as imprisonment (Article 84 [1], of the Bankruptcy and Suspension of Payment Law), (1) conduct sealing (if necessary) (Article 90 [1], of the Bankruptcy and Suspension of Payment Law)

2. The duty of managing/administering bankruptcy estate. During the bankruptcy process has not reached the state of insolvency, curator can continue the management of bankrupt debtor's businesses, as an organ of company (director), with approval from the creditors' meeting (Article 95 [1], of the Bankruptcy and Suspension of Payment Law). The management can only be done if the bankrupt debtor still has a running business. The authority of management includes (1) the authority to open all correspondences of bankrupt debtor (Article 14 in conjunction with Article 96 of the Bankruptcy and Suspension of Payment Law), (b) the authority to have a loan of third party funds, which is guaranteed by bankruptcy estate that have not been encumbered for business continuity (Article 67 [3]-[4] of 
the Bankruptcy and Suspension of Payment Law), (c) the special authority to terminate leases, employment, and other agreements.

3. The duty of selling-settling.

The most important task of curator is to make settlement. The meaning of settlement here is a situation where curator makes concurrent payments to concurrent creditors from the proceeds of the sale of bankruptcy estate.

The national bankruptcy legal system must be carried out by establishing a new law based on Pancasila and the 1945 Constitution to supports national economic development. It should guarantee certainty, order, enforcement, and legal protection to create a just and prosperous society. Therefore, the study also employed approaches of other disciplines, such as economics and politics.

As one of the options of debt payment, bankruptcy law aims to protect creditors by a clear and definite way of settlement. General explanation of the Bankruptcy and Suspension of Payment Law, which replaces the Law Number 4 of 1998, firmly adheres to the principles of balance, business continuity, justice, and integration. The general explanation of the law mentions the principle of balance as follows.

"Undang-undang ini mengatur beberapa ketentuan yang merupakan perwujudan dari asas keseimbangan, yaitu di satu pihak, terdapat ketentuan yang dapat mencegah terjadinya penyalahgunaan pranata dan lembaga kepailitan oleh debitor yang tidak jujur, di pihak lain, terdapat ketentuan yang dapat mencegah terjadinya penyalahgunaan pranata dan lembaga kepailitan oleh kreditor yang tidak beritikad baik."

[This law regulates a number of provisions that embody the principle of balance: namely, on the one hand, there are provisions that can prevent the misuse of institutions and institutions of bankruptcy by dishonest debtor; and, on the other hand, there are provisions that can prevent misuse of institutions and institutions of bankruptcy by creditors who have no good faith.]

The equal protection of interests is in line with the foundation of the Republic of Indonesia, Pancasila. Pancasila does not only recognize one's interests but also the interests of many people or society. Pancasila requires not only human rights, but also individual basic obligations. One of the principles of Pancasila is "just and civilized humanity". It demands attitude which is based on respect for others, especially for the people. It should be noted that the Bankruptcy and Suspension of Payment Law does not provide explicit provisions regarding the appointment of curator who are not from curator candidates (other party). However, the court should not appoint a curator other than the candidates for the curator proposed by debtor and creditor. This can avoid the suspicion of collusion between supervisory judge and curator appointed by judges. In addition, the court is not to be blamed if the chosen curator does not act independently and or does not act in good faith in carrying out duties.

In the practice of bankruptcy in the court, the most significant problem that arises is complaint by both creditor and bankrupt debtor against the performance of curator to the court. For example, Ali Sumali Nugroho and Iskandar Zulkarnaen were reported by one of Kymco's minority shareholders, PT Metropolitan Tirtaperdana (hereinafter 
referred to as PT. MTP), on November 22, 2012. PT MTP reported the two curators because the curator team had provided false information into an authentic deed. The false information referred to is by entering the name of the creditor that has been paid by PT. MTP to the list of creditors' bills. In addition to reporting Ali and Iskandar to the police, PT. MTP also filed a civil suit. At that time, Ali and Iskandar faced five police reports and six lawsuits. The six lawsuits included a lawsuit to the Bandung State Administrative Court against the Auction Decree for the bankruptcy estate and a lawsuit regarding the tenants of the Kymko land in the South Jakarta District Court. ${ }^{18}$

Other legal issues regarding illegal acts carried out by curator were the case of the trial of defendant Tafrizal Hasan Gewang and Denny Azani B. Latief at the Central Jakarta District Court, Jalan Gajah Mada, Central Jakarta. Tafrizal Hasan Gewang and Denny Azani B. Latief are curators who handle PT Sarana Perdana Indoglobal's (hereinafter referred to as SPI) bankruptcy estate.

The two senior curators were charged for defrauding the sale of the Podomoro Hotel, Sunter, North Jakarta, which was part of the bankruptcy estate. For this action, the two defendants were charged with multiple articles, namely Article 372 of the Criminal Code in conjunction with Article 55 (1), of the Criminal Code on embezzlement; Article 263 (1), of the Criminal Code in conjunction with Article 55 (1), of the Criminal Code on forgery of letters; Article 6 (1), of the Law Number 25 of 2003 on Money Laundering. In total, they faced 15 years in prison. In connection with the case, a hearing was held the following two days with Defendant Achmad Rivai at the Jakarta Corruption Court, Jalan H.R. Rasuna Said, South Jakarta. Rivai is the former Head of the Metro Jakarta Raya Regional Police's Youth, Children, and Women Unit who handled the SPI case. The senior police officer was charged with article of gratification and corruption. Achmad Rivai was accused of accepting Rp500 millions of bribery, or gratuities, from Johny Widjaya, a businessperson who bought the Podomoro Hotel. The money was given through Johny's lawyer, Tarida Sondang. Achmad Rivai faced a sentence of 20 years in prison. Although Tafrizal, Denny, and Rivai trials were held in two different courts, the case involving the three defendants was caused by a same problem, namely the problem of embezzling SPI's bankruptcy estate.

SPI is an investment company. Around mid-2006, SPI was the choice of the people who wanted to double their money because they offered higher interest rates than bank deposit rates. At that time, deposit interest was only around $10 \%$ per year or $0.8 \%$ per month and SPI promised to give interest up to $4 \%$ per month. In a short time, the company, which has an office in Gajah Mada Tower, Central Jakarta, was able to get 2,000 more investors with total investments of up to Rp2 trillion. In March 2007, the profits, which are received monthly by investors, were stopped. After an investigation, it was discovered that the investor's money was taken by the SPI owner, Leonardus Patar Muda Sinaga. For this incident, investors reported Leonardus and

18 Hukum Online, "Dilaporkan ke Polisi, Eks Kurator Kymko minta perlindungan AKPI", https://www.hukumonline.com/berita/baca/It52e871a8ae562/dilaporkan-ke-polisi--eks-kurator-kymco-mintaperlindungan-akpi, accessed on October 2018. 
several SPI officials to the Metro Jakarta Raya Regional Police. At the same time, investors proposed SPI's bankruptcy at the Jakarta Commercial Court.

On May 8, 2007, the Jakarta Commercial Court approved the bankruptcy proposal. Then, the supervisory judge of the Commercial Court set Tafrizal and Denny as curators to carry out the task of inventorying assets belonging to the SPI. After carrying out an inventory, then the assets are sold and the proceeds from the sale of these assets will be distributed to SPI investors (as creditors). One of the SPI bankruptcy estate is the Podomoro Hotel. To sell this hotel, the curators auctioned it twice. However, in the two auctions, the price submitted by the auction participants was still far below the price expected by the auction committee. Finally, the auction was closed without any hotel sales. Then in April 2009, the curators sold the hotel without an auction process to Johny Widjaja and Lisa Megawati. In the indictment with the defendants, Tafrizal and Denny, the prosecutor charged that there was a difference in the sale of the Podomoro hotel. The curators claimed the hotel's selling price Rp20.1 billion. However, based on the results of the police findings, the two curators sold the Podomoro Hotel for Rp25 billion. There is a difference in the price Rp5 billion as quoted in the indictment. In addition, the curators also made notes on expenses that could not be accounted for, such as curator fees, tax payments, and hotel operational costs. In total, the proceeds from the sale of hotel reached only Rp10.85 billion.

Since a bankruptcy decision brings a new legal consequence, including the debtor's assets, a bankruptcy decision must be based on rules, principles, or standards of bankruptcy and in accordance with the function of bankruptcy itself. The Commercial Court's judges must provide appropriate legal considerations and fulfill the element of justice.

Another case example is about the length of bankruptcy settlement in the bankruptcy case of PT. Kertas Paper Blabak Magelang. On the Decision of the Semarang Commercial Court Number 13/bankrupt/2010/PN.Niaga.Smg., dated November 29, 2010 on the case involving PT. Greta Sastra Prima (Applicant) and CV Putra Tunggal to PT. Kertas Blabak Magelang (Respondent). The Court declared PT. Kertas Blabak Magelang bankruptcy on November 29, 2010, but as of September 2014, there has been no settlement of bankruptcy and management of assets carried out by the curator.

Within approximately four years, there has been no legal certainty on the settlement and the management of PT. Paper Blabak Magelang. PT. Sinar Dewi Flores Indah (in bankruptcy) was declared bankrupt on January 19, 2012 by the Surabaya Commercial Court. Then on May 19, 2014 the Curator of PT. Sinar Dewi Flores Indah announced through the Kompas daily newspaper that the Curator had carried out and completed the process of management and settlement of bankruptcy estate. It was ended with the distribution of bankruptcy estate to the creditors as contained in the distribution list approved by the supervisory judge dated March 4, 2014. Based on Article 202 of the Bankruptcy and Suspension of Payment Law, the bankruptcy ends. Within a period of approximately three years, the Curator of PT. Sinar Dewi Flores Indah has completed the management and the settlement of PT. Sinar Dewi Flores Indah's bankruptcy. 
PT. Tirai Adonai Mandiri (in bankruptcy) was declared bankrupt based on the decision of the Commercial Court of the Central Jakarta District Court Number 79/pailit/2010/PN.Niaga.Jkt.Pst dated February 2, 2011. The Curator of PT. Tirai Adonai Mandiri (in bankruptcy) has completed the process of management and settlement of bankruptcy estate by announcing it in the Kompas daily newspaper dated July 3, 2014. the process was ended with the distribution of bankruptcy estate as contained in the distribution list approved by the supervisory judge dated June 25, 2014. Based on Article 192 (3), in conjunction with Article 196 (4), and Article 202 (1), of the Bankruptcy and Suspension of Payment Law, the bankruptcy of PT. Tirai Adonai Mandiri has ended. Within a period of approximately three years, the Curator of PT. Tirai Adonai Mandiri has completed the management and the settlement of bankruptcy.

Based on the three cases above, First, PT. Kertas Blabak was declared bankrupt with the Decision Number 13/bankrupt/2010/PN.Niaga.Smg dated November 29, 2010, but until 2014 the process of Management and settlement of bankruptcy estate has not yet been completed or finished. Second, the bankruptcy case of PT. Sinar Dewi Flores Indah in the Decision Number Case 35/Pailit/2011/PN.Niaga.Sby dated January 19, 2012, has been completed on March 4, 2014. the Curator, in the Kompas daily on May 19, 2014 announced the conclusion. Third, the PT. Tirai Adonai Mandiri is in the Decision Number 79/bankruptcy/2010/PN.Niaga.Jkt.Pst. Dated February 2, 2011.

The verdicts of bankruptcy cases were stated by the panel of judges as the actors of judicial power to enforce law and justice. Judicial power is subject to the law because Indonesia is a legal state. Judicial decisions must be based on law. Judicial decisions must realize justice, benefit, and legal certainty. Since the debtor has been declared bankrupt by the decision of a bankrupt statement, the legal status of the debtor becomes incompetent to carry out legal actions (rechtshandeling) in the case of possession and management of assets. Article 24 (1), of the Bankruptcy and Suspension of Payment Law states that debtor for the sake of law has lost the rights to control and to manage the assets included in the bankruptcy estate. The juridical authority was transferred to the curator based on the Article 16 (1), of the Bankruptcy and Suspension of Payment Law, despite legal remedies against the decision on the bankruptcy statement. According to Article 69 (1), of the Bankruptcy and Suspension of Payment Law, it is the task of curator to carry out the management and/or settlement of bankruptcy estate.

Several studies also show that the professionalism of curators as one of the human resources in the bankruptcy process plays a major role, especially in the Medan Commercial Court. ${ }^{19}$

Linking the provisions of Article 69 (1), and Article 74 of the Bankruptcy and Suspension of Payment Law, which states that curator must submit a report to supervisory judge on the condition of bankruptcy estate and the execution of duties in every three months, the law should provide legal consequences on the report.

19 M. Jazuri (et.al), "Pelaksanaan Fungsi Pengadilan Niaga dalam Penyelesaian Perkara Kepailitan (Suatu Analisis di Pengadilan Niaga Medan)", Jurnal IImu Hukum Pascasarjana Universitas Syiah Kuala, Vol. 1, No. 3, 2013, p. 3. 
According to Sastrawidjaja, the Bankruptcy and Suspension of Payment Law functions to protect interests of both creditors and debtors. The protection provided must be equal, balanced, not biased for both creditors and debtors. If the Bankruptcy and Suspension of Payment Law makes rules of curator's reporting, then curator will be able to exercise juridical authority properly and correctly. ${ }^{20}$

The cases described above are the reasons for the lack of proper supervision of curator's performance. So far, if the curator commits an arbitrary act, the aggrieved party, whether bankrupt debtor or creditor, usually conducts civil or criminal claims to the court. The curator must take responsibility to the debtor before the supervisory judge. The curator must return to the debtor all objects, money, books, and documents that are included in bankruptcy estate by receiving a valid receipt.

In the Bankruptcy and Suspension of Payment Law, there are no provisions that regulate criminal sanctions for parties of bankruptcy. However, it does not mean that debtor or curator who commits actions that can harm creditor or bankruptcy estate cannot be subject to criminal conduct under applicable laws. In the Criminal Code, several articles specifically regulate punishment for those who commit crimes in bankruptcy. The provisions in the Criminal Code are specifically related to bankruptcy.

Curator must be responsible for any actions that are detrimental to both debtor's bankruptcy estate and creditor's interests, intentionally or unintentionally. Article 72 of the Bankruptcy and Suspension of Payment Law states that curator is responsible for any mistakes/errors in carrying out the management and/or settlement that cause losses to bankruptcy estate. Curator may not administer and order with arbitrary actions, because if there is an action that harms bankruptcy estate, then the curator's personal property is taken into account for the act. As a form of accountability, in every 3 months, curator must submit a report to supervisory judge on the bankruptcy estate and the execution of duties (Article 74 [1], of the Bankruptcy and Suspension of Payment Law). This report is open and can be seen by the public (Article 74 [2], of the Bankruptcy and Suspension of Payment Law).

Article 77 (1), of the Bankruptcy and Suspension of Payment Law regulates creditor's resistance to curator's policy. According to the Article, every creditor, creditor committee, and bankrupt debtor can submit an objection letter to the supervisory judge of the actions taken by curator or request the supervisory judge to issue a warrant so that curator does certain deeds planned. Supervisory judge must submit the objection letter to curator no later than three days after the objection letter has been received. The curator must provide a response addressed to the supervisory judge on the objection letter no later than three days after the objection letter is received. Subsequently, the supervisory judge must provide a determination no later than three days after the response from the curator has been received (Article 77 [4], of the Bankruptcy and Suspension of Payment Law).

According to a research conducted by Purba, in practice, some curators have fulfilled the obligation to report required by Article 74 of the Bankruptcy and Suspension of Payment Law. In some regional commercial courts, there are curators

20 Man S Sastrawidjaja, op.cit., p. 73. 
who do not report due to the unclear sanctions in the Bankruptcy and Suspension of Payment Law. Both the Bankruptcy and Suspension of Payment Law and related regulations do not explain in detail and clearly the standards of the curator's report to the supervisory judge. ${ }^{21}$ It causes different forms of report on the bankruptcy estate that must be submitted in every three months to the supervisory judge. Curator only provides a report on the first bankruptcy settlement since the bankrupt decision was dropped.

Curator's report to supervisory judge on the bankruptcy estate and the execution of the curator's duties is regulated in Article 74 (1), of the Bankruptcy and Suspension of Payment Law. It states that curator must submit a report to supervisory judge on the condition of bankruptcy estate and the execution of duties in every three months. Efforts made by supervisory judge to handle curator who are not active to report is by giving a written warning in the form of a letter addressed to the curator to immediately provide the work report on bankruptcy estate. In addition to written warning, supervisory judge can also give a verbal warning. It can be done by contacting curator who has the authority to settle the bankruptcy estate. Article 74 (3) of the Bankruptcy and Suspension of Payment Law states that supervisory judge can extend the period referred to in paragraph (1) if, within a week, curator does not give report on the execution of duties to settle bankruptcy estate. Here, supervisory judge has the right to propose replacement of curator to the panel of judges of the case. Article 71 (1) of the Bankruptcy and Suspension of Payment Law states the following.

"pengadilan setiap waktu dapat mengabulkan usul penggantian kurator, setelah memanggil dan mendengar kurator, dan mengangkat kurator lain dan/ atau mengangkat kurator tambahan atas :

a. permohonan kurator sendiri;

b.permohonan kurator lainnya jika ada;

c. usul hakim pengawas;

d. permintaan debitor pailit."

[The court can at any time approve replacement of curator, after calling and hearing the curator, and appoint other curator and/or appoint additional curators on:

a. request of the curator her/himself;

b. request another curator if any;

c. proposal of supervisory judge;

d. the request of the bankrupt debtor.]

The implementation of the duties and authorities of supervisory judge in supervising the management and settlement of bankruptcy assets must refer to the Bankruptcy and Suspension of Payment Law. In practice, supervisor judge cannot fully carry out duties and authorities to oversee the management and the settlement of bankruptcy estate because curator does not provide a report in every three months.

In the Bankruptcy and Suspension of Payment Law, there are no provisions that regulate criminal sanctions for parties of bankruptcy. However, it does not mean that

21 A result of the Interview with James Purba, Chairperson of the Indonesian Curator Association on August 21, 2018. 
debtor or curator who commits actions that can harm creditor or bankruptcy estate cannot be subject to criminal conduct under applicable laws. In the Criminal Code, several articles specifically regulate punishment for those who commit crimes in bankruptcy. The provisions in the Criminal Code are specifically related to bankruptcy. ${ }^{22}$

According to Kusumaatmadja, the role of law in national development is to ensure that every change occurs in an orderly manner. Every change in every effort of development or renewal also needs an order or a harmony. Kusumaatmadja also states that in addition to establish an orderly environment, another goal of law is to achieve justice, which has various content and size according to society and its time. An orderly environment needs legal certainty. In this regard, the consideration of the Bankruptcy and Suspension of Payment Law states that the development of national law in the context of creating a just and prosperous society that is based on Pancasila and the 1945 Constitution must guarantee legal certainty. ${ }^{23}$ Legal certainty is an absolute thing in law (in this case, the bankruptcy law). Legal certainty provides certainty of the enactment of a law in a certain situation, so that it can be used as a guideline or benchmark for similar circumstances. Certainty is needed to create order and standard so that the law can play a role in accordance with its objectives ultimately.

In the modern era, there are two stages of the theory of the legal development objectives. In contrast to the three conventional teachings (ethical, utility, and legalistic), the two modern teachings are more moderate in nature by accepting all three of them as legal objectives with a certain priority scale. According to Ali's view, even though Indonesia adheres to the casuistic priority teaching theory, it must not overlook other aspects, such as benefits and justice, even though what is prioritized is one of the legal objectives, ${ }^{24}$ for example legal certainty. Similarly, the bankruptcy law is expected to be able to realize legal objectives.

\section{Conclusion}

Based on the perspective of legal certainty, the Bankruptcy and Suspension of Payment Law requires the report of debtors' bankruptcy estate by curator to supervisory judge in every three months (Article 74 of the Bankruptcy and Suspension of Payment Law). This is useful for legal certainty in resolving disputes in the commercial court. However, in practice, this is not carried out properly since there are no specific standards of the report. In addition, there is no sanction for curator who violates the requirement. Consequently, the regulation cannot assure law certainty in its practice. Therefore, it is necessary to regulate the standards of report and sanction for violations since the report is one of the most important aspects of bankruptcy process for both debtor and creditor.

22 Sutan Remy Sjahdeini, Hukum Kepailitan Memahami Undang-Undang No. 37 Tahun 2004 Tentang Kepailitan, Jakarta: PT Utama Grafiti, 2009, p. 455.

23 Mochtar Kusumaatmadja, Konsep-Konsep Hukum Dalam Pembangunan Kumpulan Karya Tulis, Bandung: PT Alumni, 2006, p. 88.

24 Achmad Ali, Menguak Teori Hukum (Legal Theory) dan Teori Peradilan (Jurisprudence) Termasuk Interpretasi Undang-undang (Legisprudence), Jakarta: Penerbit Kencana Prenadamedia Group, 2013, pp. 287-289. 
Curator's responsibility on the report to supervisory judge is related to the principle of certainty to guarantee legal certainty as a means of debt settlement in Indonesia. The 1945 Constitution is the general legal ground and the Bankruptcy and Suspension of Payment Law is the specific legal ground. If curator does not perform the duties properly or negligently, then the curator should be responsible personally.

\section{References}

Books

Achmad Ali, Menguak Teori Hukum (Legal Theory) dan Teori Peradilan (Jurisprudence)

Termasuk Interpretasi Undang-undang (Legisprudence), Penerbit Kencana Prenadamedia Group, Jakarta, 2013.

Achmad Yani dan Gunawan Widjaja, Seri Hukum Bisnis Kepailitan, PT Raja GrafindoPersada, Jakarta, 2002.

Gunawan Widjaja, Risiko hukum \& Bisnis Perusahaan Pailit, Forum Sahabat, Jakarta, 2009.

Imran Nating, Peranan dan Tanggug Jawab Kurator dalam Pengurusan dan Pemberesan Harta Pailit, PT RajaGrafindo Persada, Jakarta, 2004.

Man S Sastrawidjaja, Hukum Kepailitan dan Penundaan Kewajiban Pembayaran Utang, PT Alumni, Bandung, 2006.

Mochtar Kusumaatmadja, Hukum, Masyarakat dan Pembinaan Hukum Nasional, Bina Cipta, Bandung, 1976.

Mochtar Kusumaatmadja, Konsep-Konsep Hukum Dalam Pembangunan Kumpulan Karya Tulis, PT Alumni, Bandung, 2006.

Munir Fuady, Hukum Pailit dalam Teori dan Praktek, PT Citra Aditya Bakti, Bandung, 2014.

Sutan Remy Sjahdeini, Hukum Kepailitan Memahami Undang-Undang No. 37 Tahun 2004 Tentang Kepailitan, PT Utama Grafiti, Jakarta, 2009.

\section{Dokumen Lain}

Cholidah Utama,"Tanggung Jawab Hakim Pengawas dalam Pengurusan Harta Debitor Pasca Pailit", Jurnal Muamalah, Vol. 3, No. 1, 2017.

Dewi Tuti Maryati (et.al),"Pengaturan Tanggung Jawab Kurator Terhadap Pengurusan dan Pemberesan Harta Pailit dalam Kaitannya dengan Hak Kreditor Separatis", Jurnal Dinamika Sosial Budaya, Vol. 19, No. 1, Juni 2017.

Ema Rahmawati,"Putusan Pailit Sekutu Pengurus Persekutuan Komanditer (CV) Atas Utang Perusahaan Dalam Kajian Hukum Kepailitan dan Kitab Undang-Undang Hukum Dagang", Tesis, Program Studi Ilmu Hukum Pascasarjana, Universitas Padjadjaran, 2009.

Hukum Online,"Dilaporkan ke Polisi, Eks Kurator Kymko minta perlindungan AKPI", https://www.hukumonline.com/berita/baca/lt52e871a8ae562/dilaporkan-kepolisi--eks-kurator-kymco-minta-perlindungan-akpi, accessed on October 2018.

Hukum Online,"Kurator Tanggapi Sema Efisiensi Perkara Kepailitan", https://www.hukumonline.com/berita/baca/lt57d22b7635191/kurator-tanggapisema-efisiensi-perkara-kepailitan, accessed on October 2018. 
M. Jazuri (et.al),"Pelaksanaan Fungsi Pengadilan Niaga dalam Penyelesaian Perkara Kepailitan (Suatu Analisis di Pengadilan Niaga Medan)", Jurnal Ilmu Hukum Pascasarjana Universitas Syiah Kuala, Vol. 1, No. 3, 2013.

Poppy Indaryati, "Diskriminasi Kurator di dalam Kepailitan", Postgraduate Thesis, Universitas Diponegoro Semarang.

Syafrudin Makmur,"Kepastian Hukum Kepailitan Bagi Kreditur dan Debitur Pada Pengadilan Niaga Indonesia", Mizan Jurnal IImu Syariah, Vol. 4, No. 2, 2016.

Tata Wijayanta,"Asas Kepastian Hukum, Keadilan dan Kemanfaatan dalam Kaitannya dengan Putusan Kepailitan Pengadilan Niaga", Jurnal Dinamika Hukum, Vol. 14, No. $2,2014$.

\section{Law Documents}

The 1945 Constitution of the Republic of Indonesia.

Book of Civil Code [Kitab Undang-Undang Hukum Perdata].

Book of Commercial Code [Kitab Undang-Undang Hukum Dagang].

Law Number 37 of 2004 on Bankruptcy and Suspension of Payment [Undang-Undang Nomor 37 Tahun 2004 tentang Kepailitan dan Penundaan Pembayaran Utang].

Law Number 48 of 2009 on Judicial Authority [Undang-Undang Nomor 48 Tahun 2009 tentang Kekuasaan Kehakiman].

Law Number 49 of 2009 on General Judicature [Undang-Undang Nomor 49 Tahun 2009 tentang Peradilan Umum]. 